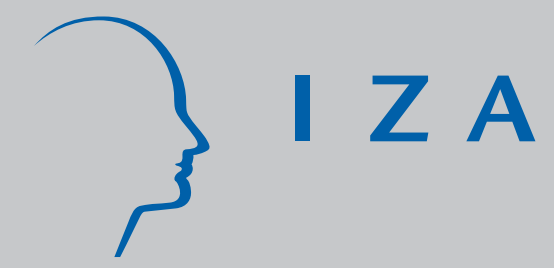

IZA DP No. 1551

At the Lower End of the Table:

Determinants of Poverty among Immigrants to

Denmark and Sweden

Kræn Blume

Björn Gustafsson

Peder J . Pedersen

Mette Verner

April 2005 


\title{
At the Lower End of the Table: Determinants of Poverty among Immigrants to Denmark and Sweden
}

\author{
Kræn Blume \\ Institute for Local Government Studies, Copenhagen \\ Björn Gustafsson \\ University of Gothenburg and IZA Bonn \\ Peder J. Pedersen \\ University of Aarhus, National Institute of Social Research, Copenhagen \\ and IZA Bonn \\ Mette Verner \\ Aarhus School of Business
}

Discussion Paper No. 1551

April 2005

IZA

P.O. Box 7240

53072 Bonn

Germany

Phone: +49-228-3894-0

Fax: +49-228-3894-180

Email: iza@iza.org

\begin{abstract}
Any opinions expressed here are those of the author(s) and not those of the institute. Research disseminated by IZA may include views on policy, but the institute itself takes no institutional policy positions.

The Institute for the Study of Labor (IZA) in Bonn is a local and virtual international research center and a place of communication between science, politics and business. IZA is an independent nonprofit company supported by Deutsche Post World Net. The center is associated with the University of Bonn and offers a stimulating research environment through its research networks, research support, and visitors and doctoral programs. IZA engages in (i) original and internationally competitive research in all fields of labor economics, (ii) development of policy concepts, and (iii) dissemination of research results and concepts to the interested public.
\end{abstract}

IZA Discussion Papers often represent preliminary work and are circulated to encourage discussion. Citation of such a paper should account for its provisional character. A revised version may be available directly from the author. 


\section{ABSTRACT \\ At the Lower End of the Table: Determinants of Poverty among Immigrants to Denmark and Sweden*}

In this paper we study determinants of relative poverty among immigrants and natives in Denmark and Sweden during the 1980s and 1990s. Denmark and Sweden share the same properties in a range of labour market and welfare state characteristics. At the same time they differ very much in cyclical profiles and immigration experiences during recent decades. Both countries have followed the same principles regarding immigration policy, i.e. immigration from low income countries has been restricted to tied movers and refugees. We use 60 percent of the median in the distribution of equivalent disposable as poverty line. Data comes from two large panels based on administrative data. We find that immigrants have higher poverty rates than natives in both countries and that this difference has clearly increased in both countries. The paper reports results based on running probability models of poverty incidence. Explanatory variables include measures of years since immigration, demographic characteristics, and variables measuring country of origin. We conclude that a significant part of the difference in aggregate immigrant poverty rates reflect differences in composition by country of origin and differences in the structure of benefits to families with children.

JEL Classification: F22, I32, J15

Keywords: poverty, immigrants, panel data

Corresponding author:

Peder J. Pedersen

Department of Economics

B 322, University of Aarhus

DK-8000 Aarhus C

Denmark

Email: ppedersen@econ.au.dk

\footnotetext{
* David Skovmand and Anette K. Jensen have been very efficient research assistants. An earlier version of the paper was presented at a Workshop in Rørvig. April 2004. Comments from the discussant Jens Clausen and other participants and from participants at a seminar at Department of Economics, University of Aarhus, are gratefully acknowledged.
} 


\section{Introduction}

The purpose in this paper is to study some of the factors behind the incidence of low income among immigrants to two Scandinavian welfare states, Sweden and Denmark, relative to the native population. Rather few studies exist focusing on immigrant poverty in host countries. An obvious motivation for the present study is thus the widespread lack of sufficient knowledge in an important area. Further, we are able to base our analysis on two highly comparable sets of panel data for two countries with an interesting set of both similarities and differences over the period we study from the mid-1980s.

While net immigration, especially from less developed countries towards high income OECD countries, has been increasing strongly in recent decades, only few studies exist on the income position among the immigrants. Most of the available studies are cross section analyses of the low income shares by ethnic origin relative to the native population in the destination country. Summary cross section data shows very big differences in low income shares which to an unknown degree could reflect differences in arrival patterns and thus duration of stay in the new country of residence, and differences regarding educational qualifications at the time of entry. Other important factors are related to the type of immigration, i.e. whether immigration is job or study related, whether it is a case of family re-unification as a tied mover or whether the immigrant arrives initially as a refugee. Obviously, the background for residence in the host country is expected to have a major impact on the incidence of low income and in the longer run on income mobility.

Studies on cross section data where the only distinction is by country of origin show very big differences regarding the poverty risk, see e.g. Borjas (1990) for the U.S.A. and Kazemipur and Halli (2001) for Canada. With U.S. 1980 data Borjas finds a range between 6 and 37 per cent in the poverty rates for 42 groups of immigrants by national origin. Swedish studies including information on time of arrival to Sweden also find big differences between immigrants from different countries. At the same time they find the expected significant impact from the duration of residence in Sweden and from education, see Ekberg (1994), Gustafsson (1997, 1999) and Hammarstedt (2001).

A descriptive survey of the low income risk in Denmark and Sweden also based on the panel data sets used in the present paper can be found in Blume et al. (2005). A main conclusion in this paper was the finding of increasing gaps in poverty rates between natives and immigrants in both countries reflecting increasing poverty rates among immigrants from less developed countries. The increasing gap is most pronounced in Denmark where the low income share among natives has remained stable since the mid-1980s while it has been increasing for natives in Sweden. Another 
finding was decreasing poverty rates with number of years since migration among immigrants from more developed countries while this in general did not appeared to be the case for immigrants from less developed countries. Further, in both countries we find that new cohorts of immigrants from less developed countries have increasingly higher poverty rates after a given number of years since migration. An important topic in the present paper is to make a first attempt towards a multivariate analysis of the incidence of low income while a more dynamic approach is the topic for future work.

In the following Section 2 describes some of these similarities and differences between the two countries regarding the aggregate cyclical profile, the public sector and the development in the stock and inflow of immigrants. Further, Section 2 contains a brief description of the labour market performance of immigrants, i.e. regarding labour market participation and unemployment. Next, Section 3 describes the two panel data sets and the poverty lines being used in the study. Section 4 presents the results regarding the incidence of low income in a selected number of years in the period. Results from the rich micro data sets are used in Section 5 to calculate the poverty risk for a number of typical individuals, immigrants as well as natives, defined by setting specific values for the individual background variables. Finally, Section 6 concludes the paper.

\section{Background}

Sweden and Denmark have labour markets with a number of common characteristics such as high levels of unionization, high relative minimum wages, a low variance in the earnings distribution and a big role for the public sector as employer and finally both countries have female participation rates very close to the level for men. Further, both countries have experienced a secular shift away from low-skilled industrial jobs towards service sector jobs with higher demands on social and language skills, i.e. “dirty” and simple industrial jobs with people working to a great extent alone, based on simple instructions, have been replaced to a big extent by jobs in more or less selfgoverning groups putting emphasis on communicative and social skills. The consequences of these trends for the employment and - implicitly the income - among immigrants from less developed countries are the topic of an interesting analysis by Rosholm et al. (2000). The wage structure as well as characteristics of the job structure thus create barriers for a fast labour market entry for new immigrants from less developed countries with modest or low education at entry to the host country. The public sector in the two countries also show a number of similarities. It is well known that the tax/GNP ratios in Sweden and Denmark are the highest in the OECD area and that many benefits as 
a reflection of this are universal based only on residence in the country. The structure of taxes differ somewhat with more emphasis on the direct personal income tax in Denmark and more emphasis on labour market contributions in Sweden. On the benefit side both countries have the same principles regarding unemployment insurance which is based on the Ghent principle, i.e. administratively connected with unions and in principle a voluntary program. Supplementary to unemployment insurance both countries have programs for means tested welfare benefits. Benefits to families with dependent children is a lump sum amount dependent on the number of children, but not means tested against family income if both parents live in the family. Higher benefits are available to child families led by a single parent.

Further, housing benefits for people living in rented dwellings are means tested against family income. At the same time, the public sector in both countries offers a wide range of services in the areas of education, health, child and elderly care either free or at a low cost and the level of inequality in the distribution of disposable incomes is low after inclusion of the big equalizing effects from highly progressive taxes and regressive transfers. Finally, Sweden and Denmark have for the period we study followed the same basic principles regarding immigration policy implying that immigration from less developed countries has been restricted to family re-unions and refugees. At the same time a number of differences are part of the story regarding our two countries. The macroeconomic background has been very different for the period on which we focus. During the first part of the period unemployment was high and mostly increasing in Denmark while Sweden experienced full employment or even excess demand for labour as shown in Figure 1. Then, in the early 1990s Sweden was hit by a strong negative shock with a big increase in unemployment along with a decline in participation rates followed by recovery in the more recent years. The Danish economy turned around from 1994 experiencing a big decline in unemployment rates until recently. Nevertheless, in spite of these big cyclical differences, both countries have experienced the same problem of high unemployment among immigrants from less developed countries in the 1990s.

Other big differences regarding the topic in focus in the present paper are found regarding the composition both regarding flows and stocks of immigrants by national origin coming to Sweden and Denmark. Also, the inflow rates of immigrants have differed. A final observation is the fact that the initial stock of immigrants relative to the population was much higher in Sweden but that the relative increase in the number of immigrants in Denmark has been higher throughout the period we study with 1989 and 1994 as the only exceptions, cf. Figure 2. 
Figure 1. OECD standardised unemployment rates, Sweden and Denmark, 1984-1997.

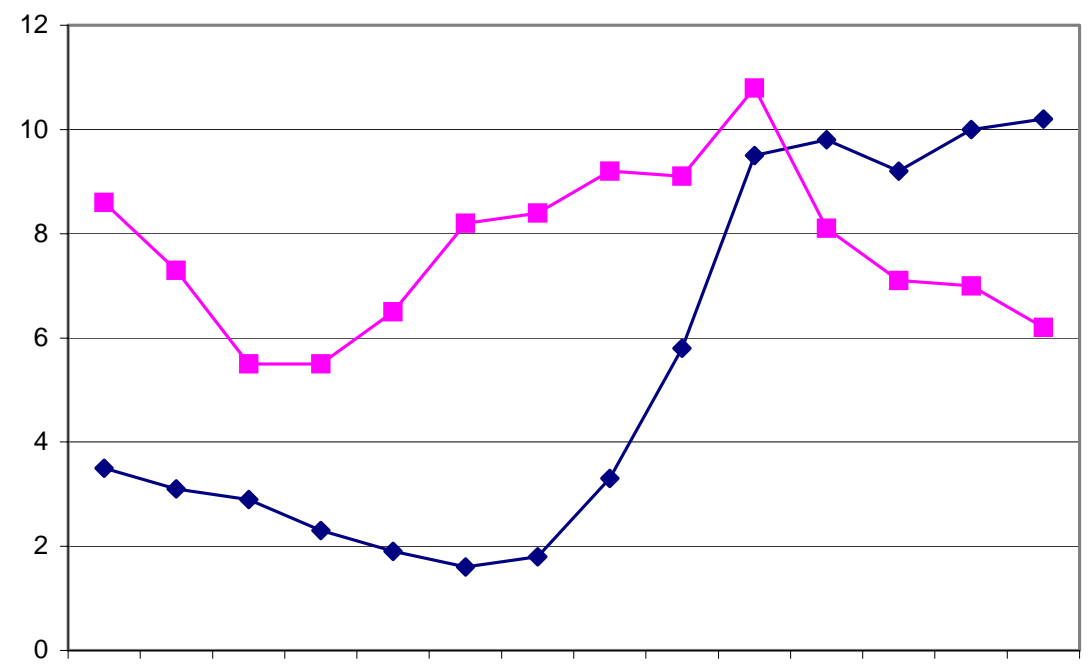

19841985198619871988198919901991199219931994199519961997

Sweden - Denmark

Figure 2. Relative Changes in the Stock of Immigrants in Sweden and Denmark, 1985-1997.

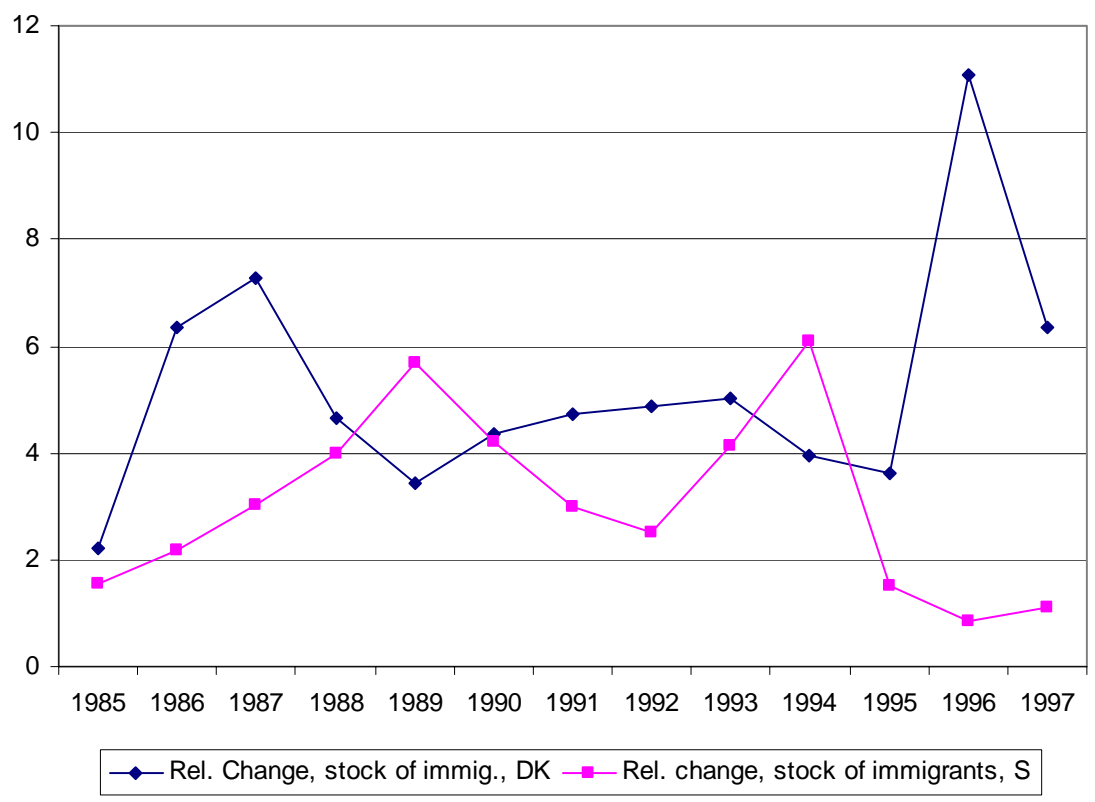

Another major difference regarding immigration to Sweden and Denmark appears when we look in more detail on the composition of the population of immigrants by national origin. Following the 
UN classification of countries into more and less developed, we find the composition of the stock of immigrants on these two groups of countries as shown in Figure $3^{1}$. At each point in time the share of people from less developed countries is higher in Denmark with the share reaching 50 per cent in 2000. Part of the lower share in Sweden reflects the very high number of people from Finland which is an exception in contrast to the relatively low level of other cross-national migration flows between the Nordic countries. Between 1980 and 2000 the absolute number of immigrants from Finland goes down from 251.342 to 195.447. In relative terms the share of immigrants from Finland goes down much more dramatically from 40.1 per cent to 19.5 per cent. In Figure 3 we show also the share of people in Sweden born abroad who come from the group of less developed countries when people born in Finland are excluded. But also in this setting we find a higher share from less developed countries in Denmark.

Figure 3. The Relative Share of Immigrants in Sweden and Denmark from less Developed Countries, 1980-2000.

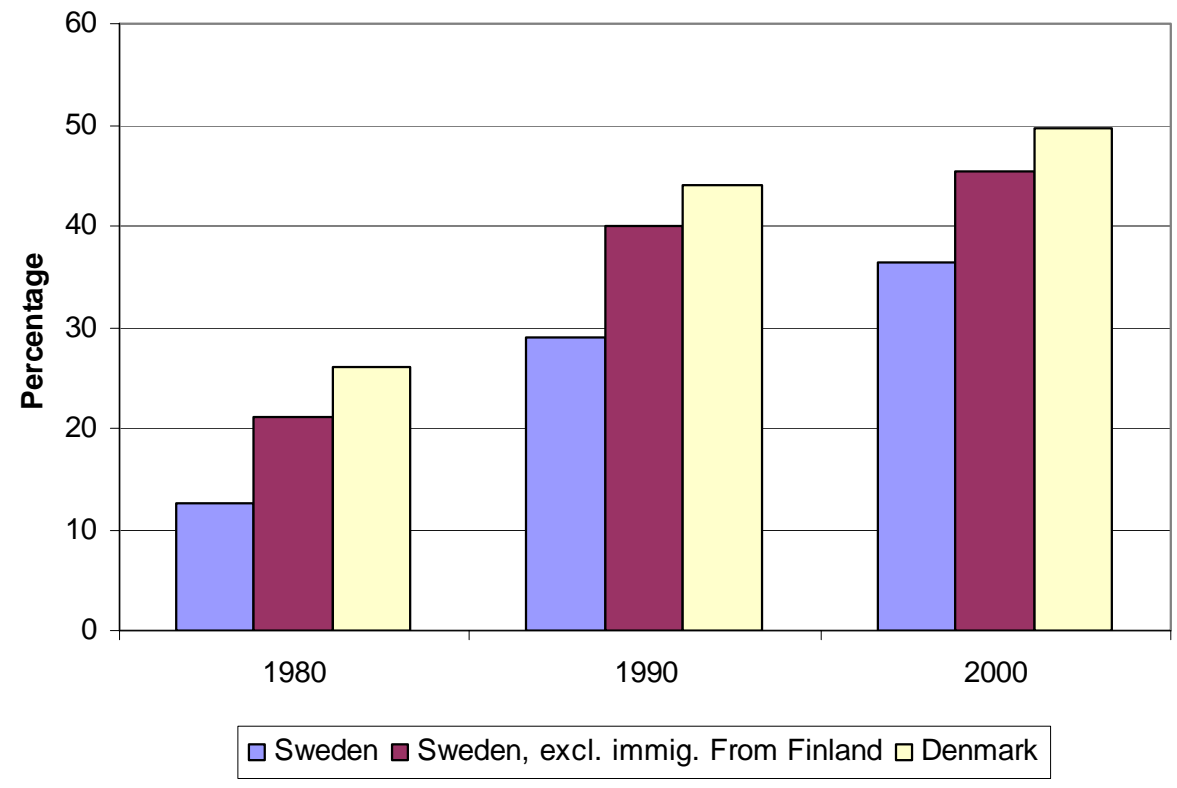

Another aspect of the differences in the composition by origin of immigrants is illustrated in Table 1 showing the number of immigrants coming from the nine non-western countries from which the

\footnotetext{
${ }^{1}$ The group of more developed countries consist by this classification of all European countries, excl. Turkey, Cyprus and a number of former Soviet republics, USA, Canada, Japan, Australia and New Zealand, cf. Poulsen and Lange (1998).
} 
greatest number of immigrants live in Sweden, respectively Denmark ${ }^{2}$. It is obvious from the table that the ranking by country of origin differs between Sweden and Denmark. Two countries, Chile and Syria, appear only in the Swedish panel of the table, while Somalia and Pakistan appear only in the Danish panel. Only one country, Turkey, has roughly the same number of immigrants in Denmark and Sweden.

Table 1. Number of Residents from Major Non-Western Immigration Countries. Sweden and

Denmark. 2001

\begin{tabular}{|ll|ll|}
\hline \multicolumn{2}{|c|}{ Sweden } & \multicolumn{2}{c|}{ Denmark } \\
\hline Ex-Jugoslavia & 73.274 & Turkey & 18.027 \\
\hline Iraq & 55.696 & Bosnia-Herzegovina & 15.099 \\
\hline Bosnia-Herzegovina & 52.198 & Iraq & 12.545 \\
\hline Iran & 51.844 & Ex-Jugoslavia & 11.924 \\
\hline Poland & 40.506 & Lebanon & 11.847 \\
\hline Turkey & 32.453 & Somalia & 11.348 \\
\hline Chile & 27.153 & Iran & 10.391 \\
\hline Lebanon & 20.228 & Poland & 10.313 \\
\hline Syria & 14.646 & Pakistan & \\
\hline
\end{tabular}

Employment is obviously an important factor regarding the low income risk. Figure 4 illustrates the challenge faced by Sweden as well as Denmark regarding succesfull labour market integration of immigrants. For 1997, the most recent year in the databases we use, we find the same profiles in both countries, i.e. very high employment rates among native born, and much lower among immigrants. This is most pronounced among immigrants from less developed countries with employment rates close to half the level among the native born.

\footnotetext{
${ }^{2}$ The classification defines non-western countries as being those outside the small group of rich OECD countries consisting of the EU countries prior to the 2004 enlargement, USA, Canada, Australia, New Zealand and Japan. This classification is also used in Schultz-Nielsen (2001) and in Wadensjö and Orrje (2002).
} 
Figure 4. Employment rates for immigrants and natives in 1997, 16 - 64 years. Sweden and Denmark ${ }^{3}$.

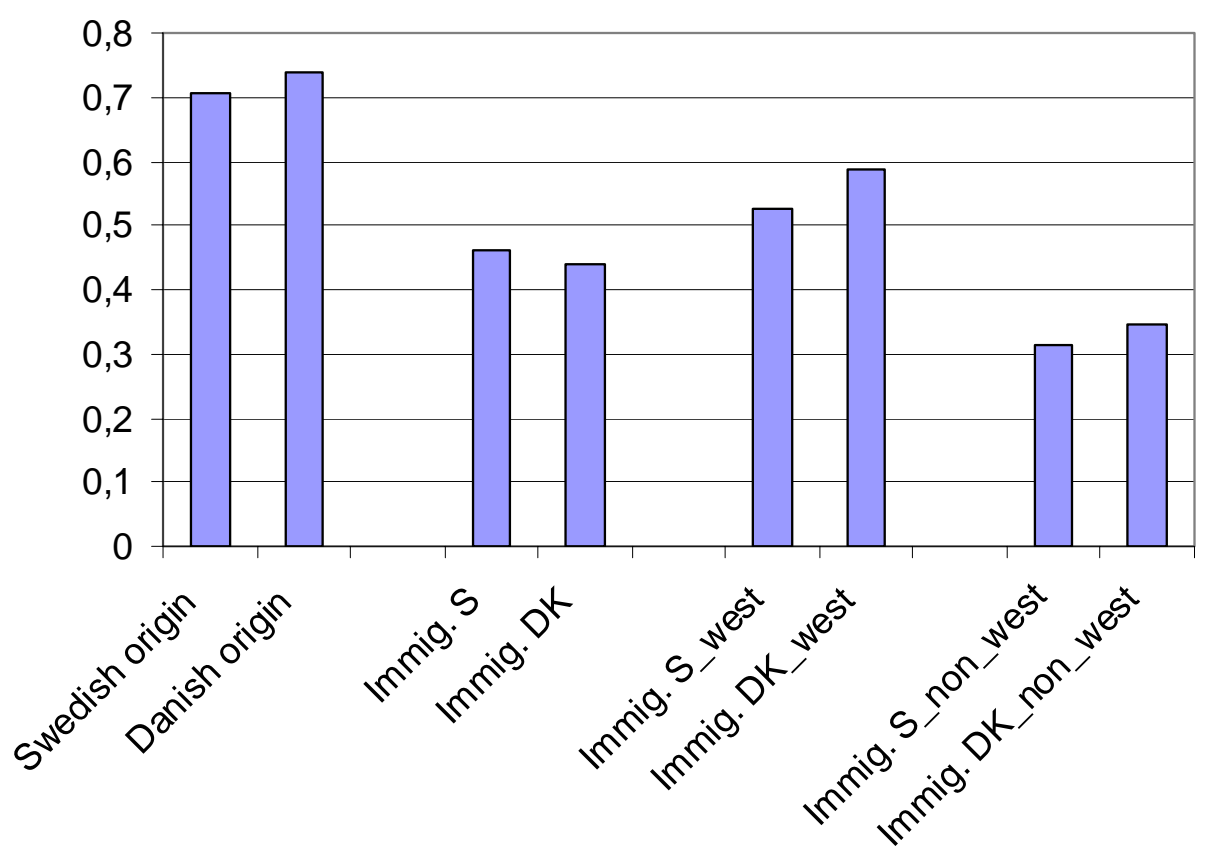

\section{Data and Poverty Line}

\section{Swedish data}

The data used to describe the Swedish case in this study is coming from the socalled SWIP database (Swedish Income Panel). It consists of 10 per cent of the Swedish immigrant population originally drawn for from the population residing in Sweden 1978 and updated with later arrivals as well as a 1 per cent sample of the native Swedish population ${ }^{4}$. It is based on administrative registers and contains a big number of demographic, labour market and income variables. In the present study we use observations for the years 1984 - 1997. Immigrants are in this sample defined as persons born outside Sweden. This dataset has the same advantage as the Danish data of including a large number of foreign-born compared to samples typically being used when measuring poverty. There

\footnotetext{
${ }^{3}$ Country categories may differ slightly. Calculations from Statistics Sweden and Statistics Denmark. Immigrants defined as being born abroad with parents being foreign citizens).

${ }^{4}$ In the present study we restrict the analyses of Swedish data to the period ending in 1997 which was available when the study was made. We start the analysis from 1983 as from that year disposable income is measured more accurate than before.
} 
is also the advantage of the panel property making it possible to follow persons over time and to apply a longer observation period than one year. However, a disadvantage is the narrow definition of a family. A family is defined as consisting of one or two adults and their children and a person is regarded as an adult when turning 18. Most important, young adults 18 and older living with their parents are treated as a separate unit, and as a consequence many young people reported to have high poverty rates in reality might share income with their parents. This has to be kept in mind when interpreting results for young adults, but as the definition of a family is the same in the datasets for Denmark the cross country comparison should not be distorted because of this.

\section{Danish data}

The Danish dataset is extracted from the Institute of Local Government Studies (AKF) panel database building on administrative registers in Statistics Denmark and covering the period since 1984. The panel data set contains a big number of demographic, labour market, incomes, taxes and benefit variables. The data consist of 100 per cent of the immigrants and their children and a 10 per cent representative sample of the whole population. This sampling scheme thus involves an overlap between the representative population sample and the immigrant sample. The classification of persons into immigrants, descendants and natives follows the definitions applied by Statistics Denmark, see Poulsen and Lange (1998). They differ, although only slightly, from the Swedish classification criteria, i.e. being born in or outside Sweden.

\section{The low-income measure}

In order to construct our low-income line (or poverty line), in accordance with the recommendations in Atkinson et al. (2002), we use 60 per cent of the median in the distribution of equivalence adjusted disposable incomes as the cut off point. We use the OECD equivalence scale applied to disposable household incomes (including child support and subsidies to housing rents) to convert to individual incomes, i.e. the weight is 1.0 for first adult in household, 0.7 for other adult persons and 0.5 for every child. The equivalence scale adjusted household income is assigned to each member of the household and each household is assigned a weight equal to the number of members irrespective of age. It should be noted that the low-income line is calculated from the income distribution for the full representative samples, i.e. including individuals of all ages. In the analysis below, however, only individuals aged 18-65 are included.

In Figure 5 we show some crude indicators for the development in the low income shares for immigrants and natives in Sweden and Denmark between 1984 and 1997. Looking first at the 
situation among natives we find the same level of the low income share until the early 1990s. Following the deep depression in Sweden from 1990, the low income share increases from 10 to 15 per cent while the level remains stable in Denmark and thus appears as completely robust in relation to the big cyclical changes throughout the period. Turning to the situation among immigrants, the low income shares increase in both countries and the level is significantly higher in Denmark during the whole period. Further, the native-immigrant gap with respect to low income shares increases much more in Denmark than in Sweden. It should be emphasized, however, that the crude measures in Figure 5 are influenced by the composition of the immigrants on national origin and time of residence in the host country. A detailed descriptive study of the low income shares for different groups of immigrants can be found in Blume et al. (2003).

Figure 5. Low Income Shares, Immigrants and Natives, Denmark and Sweden, 1984-1997

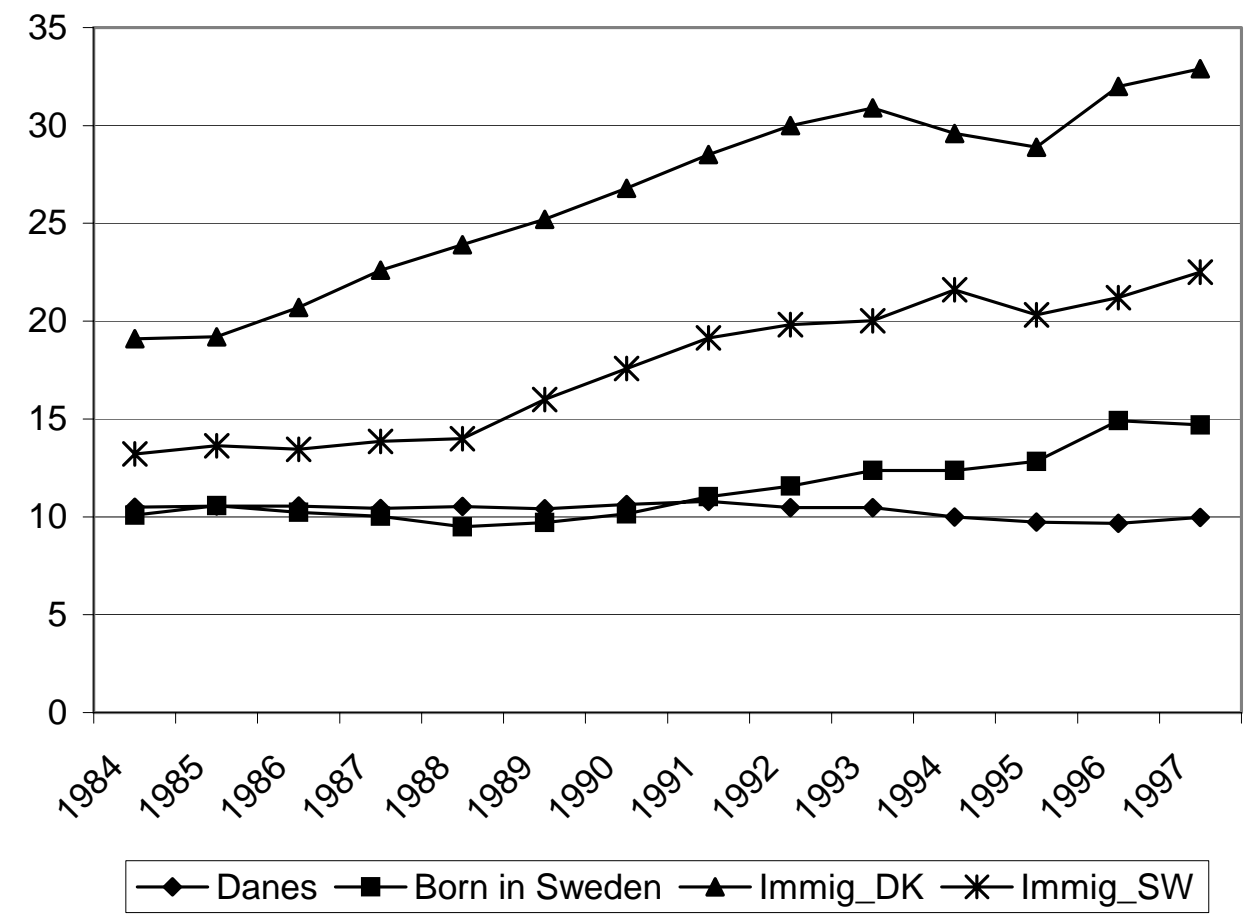

\section{Results}

The low income shares shown in Figure 5 are the aggregate outcome from a multitude of factors including among others the age of immigrants, their family situation, national origin, age at arrival to the host country, the number of years since arrival and the labour market success or not of the immigrant. The impact from this multitude of background factors on the low income risk has been 
analysed using probit analyses. We have selected three years, 1984, 1990, and 1997 as representatives for the analyses. The results for Sweden are shown in Table 2.

Table 2. Determinants of low income incidence in 1984, 1990 and 1997. First generation immigrants to Sweden and natives.

\begin{tabular}{|c|c|c|c|c|c|c|}
\hline & \multicolumn{2}{|c|}{1984} & \multicolumn{2}{|c|}{1990} & \multicolumn{2}{|c|}{1997} \\
\hline & Coefficient & Std. Dev. & Coefficient & Std. Dev. & Coefficient & Std. Dev. \\
\hline Constant & -0.7730 & 0.0045 & -0.8236 & 0.0045 & -0.4236 & 0.0041 \\
\hline Age 39 & -0.5387 & 0.0073 & -0.5117 & 0.0070 & $\begin{array}{l}-0.8630 \\
\end{array}$ & 0.0062 \\
\hline Age 49 & -0.5558 & 0.0079 & -0.5955 & 0.0074 & -1.0037 & 0.0071 \\
\hline Age 59 & -0.5819 & 0.0093 & -0.6028 & 0.0092 & -1.0554 & 0.0079 \\
\hline Age 60 & -0.6881 & 0.0117 & -0.6485 & 0.0120 & -1.1320 & 0.0121 \\
\hline Single, child & -0.0350 & 0.0112 & 0.1527 & 0.0095 & 0.2684 & 0.0081 \\
\hline Couple, 0 ch. & -0.6476 & 0.0095 & -0.6700 & 0.0093 & -0.7095 & 0.0087 \\
\hline Couple, $1-2$ ch. & -0.4574 & 0.0070 & -0.5920 & 0.0074 & -0.5736 & 0.0071 \\
\hline Couple, 3 ch. & $\begin{array}{l}-0.0863 \\
\end{array}$ & 0.0124 & $\begin{array}{l}-0.0909 \\
\end{array}$ & 0.0124 & $\begin{array}{l}-0.1967 \\
\end{array}$ & 0.0117 \\
\hline Couple, 4+ & 0.3724 & 0.0219 & 0.3897 & 0.0185 & 0.5059 & 0.0163 \\
\hline Arr06 & 1.4416 & 0.0478 & 0.7277 & 0.0279 & 0.4299 & 0.0182 \\
\hline Arr718 & 0.6188 & 0.0205 & 0.6518 & 0.0137 & 0.3274 & 0.0104 \\
\hline Arrage18plus & 0.6231 & 0.0107 & 0.5621 & 0.0079 & 0.4786 & 0.0064 \\
\hline Arr68 & -0.1713 & 0.0529 & -0.2576 & 0.0556 & -0.0083 & 0.0582 \\
\hline Woman & 0.0132 & 0.0050 & 0.0145 & 0.0050 & 0.0602 & 0.0045 \\
\hline MDC & 0.2693 & 0.0239 & 0.4414 & 0.0176 & 0.5296 & 0.0157 \\
\hline Turkey & 0.6334 & 0.0510 & 0.8668 & 0.0365 & 1.1712 & 0.0336 \\
\hline Ex-Yugo & 0.2297 & 0.0298 & 0.1746 & 0.0289 & 0.1124 & 0.0226 \\
\hline Iraq & 0.3796 & 0.0864 & 0.3703 & 0.0497 & 0.6166 & 0.0297 \\
\hline Poland & -0.0065 & 0.0372 & 0.0103 & 0.0323 & -0.0119 & 0.0297 \\
\hline Lebanon & - & - & - & - & 0.9076 & 0.0352 \\
\hline Chile & 0.2688 & 0.0595 & 0.0408 & 0.0370 & 0.3522 & 0.0354 \\
\hline $\begin{array}{l}\text { Iran } \\
\end{array}$ & 0.7472 & 0.0621 & 0.2085 & 0.0283 & 0.6264 & 0.0271 \\
\hline Other countries & 0.4696 & 0.0367 & 0.4922 & 0.0213 & 0.5974 & 0.0198 \\
\hline YSM_MDC & -0.0886 & 0.0029 & -0.0639 & 0.0017 & $\begin{array}{l}-0.0503 \\
\end{array}$ & 0.0013 \\
\hline YSM_MDC2 & 0.0010 & 0.0000 & 0.0006 & 0.0000 & 0.0005 & 0.0000 \\
\hline YSM_LDC & -0.0894 & 0.0058 & -0.0376 & 0.0026 & -0.0391 & 0.0018 \\
\hline YSM_LDC2 & 0.0011 & 0.0001 & 0.0004 & 0.0000 & 0.0004 & 0.0000 \\
\hline No. of observations & & 103068 & & 116787 & & 129705 \\
\hline Log likelihood & & $\begin{array}{l}-159860 \\
\end{array}$ & & -167367 & & -214205 \\
\hline
\end{tabular}

The first group of variables is the age of immigrants in a number of intervals with individuals younger than 30 as the reference group. In all three years we find significantly negative coefficients, i.e. a lower poverty risk for immigrants 30 and older, including the 60 years and older group with less attachment to the labour market. The next block of variables report results regarding family 
status with being single and without children as the left out category. Couples with 4 or more children have a significantly higher risk of being in the low income category while all other living in couples have a significantly lower risk. For single parents we find a significantly higher poverty risk in 1990 and 1997 while the coefficient surprisingly is significant and negative in 1984. As immigrants have more children than natives have, this part of the results is a clear indication at least for the later part of the period that poverty in Sweden is becoming a phenomenon with high incidence among immigrants with big families.

The next group of variables are dummies for three categories of arrival ages to Sweden, i.e. 0-6 years implying that all schooling has been received in Sweden, 7-18 years where part of schooling has been received in Sweden and finally a dummy variable for those arriving older than 18 years having had only their eventual vocational or theoretical education in Sweden. All the coefficients are significantly positive with native born being the left out category. The relative size of the coefficients do, however, not reflect any significant advantage regarding the low income risk from having a Swedish school education.

Next, due to lack of data, we enter a dummy variable set at 1 for immigrants who arrived earlier than 1968. This is the period where immigration typically was to a job which explains the significantly negative impact on the low income risk from this variable in both 1984 and 1990. In 1997 the coefficient is insignificant, probably reflecting that a major part of this group has entered early or normal retirement in the late 1990s. Further, being a woman is associated with a significantly higher poverty risk.

The next block of variables captures the impact from a number of indicators of the national origin of immigrants to Sweden. We enter dummy variables for coming from the group of socalled more developed countries, cf. fn. 1, from the seven socalled less developed or non-western countries with the highest number of immigrants in Sweden and from the residual group of countries. The low income risk is thus measured relative to the excluded group of native Swedes. Regarding national origin we find significant positive coefficients, except for Chile in 1990 and for Poland in all three years where the coefficients are insignificant. The coefficients are also positive and significant for immigrants from the group of socalled more developed countries in all three years. Finally, we enter years since migration interacted with respectively coming from the group of more developed countries or from the group of less developed countries. To capture eventual non-linearities we also enter the squared form of this interaction variable. For immigrants coming from the group of more developed countries we find a significant negative coefficient in all three years indicating an 
expected pattern of the low income risk decreasing with time since immigration. For the less developed countries group the coefficient is also significant and negative indicating a decreasing low income risk as duration of residence in Sweden increases. It should be mentioned however, that it is not straightforward to compare the coefficients to years since migration for immigrants coming from the two country groups. This is due to the major differences regarding return migration which is high for those coming from the more developed countries group while it is mostly very low for people coming from the group of less developed countries, see Klinthäll (2003) and Jensen and Pedersen (2004). Thus, selectivity is much more important regarding immigrants from more developed countries who remain in Denmark or Sweden.

The same probit estimations have been run with Danish data where the only difference is that some of the most important countries of origin are others than for Sweden, cf. Table 1. The results are shown in Table 3. As the structure is the same in Tables 2 and 3 we shall concentrate the comments on the results in Table 3 to the differences between the Swedish and the Danish results. 
Table 3. Determinants of low income incidence in 1984, 1990 and 1997. First generation immigrants and natives. Denmark.

\begin{tabular}{|c|c|c|c|c|c|c|}
\hline & \multicolumn{2}{|c|}{1984} & \multicolumn{2}{|c|}{1990} & \multicolumn{2}{|c|}{1997} \\
\hline & Coefficient & Std. Dev. & Coefficient & Std. Dev. & Coefficient & Std. Dev. \\
\hline Constant & -0.7445 & 0.0020 & -0.5187 & 0.0019 & -0.3808 & 0.0019 \\
\hline Age 39 & -0.5250 & 0.0031 & -0.6680 & 0.0031 & -0.8405 & 0.0031 \\
\hline Age 49 & -0.5917 & 0.0034 & -0.8552 & 0.0033 & $-1,1303$ & 0.0036 \\
\hline Age 59 & -0.4667 & 0.0036 & -0.8459 & 0.0039 & -1.2247 & 0.0041 \\
\hline Age 60 & -0.0711 & 0.0037 & -0.5027 & 0.0041 & -0.8992 & 0.0048 \\
\hline Single, child & 0.3711 & 0.0043 & 0.3105 & 0.0041 & 0.3097 & 0.0043 \\
\hline Couple, 0 ch. & -0.7915 & 0.0029 & -0.8665 & 0.0029 & -0.9637 & 0.0031 \\
\hline Couple, $1-2$ ch. & -0.7766 & 0.0030 & -0.9812 & 0.0033 & -1.0801 & 0.0035 \\
\hline Couple, 3 ch. & -0.0541 & 0.0052 & -0.2929 & 0.0059 & -0.3761 & 0.0058 \\
\hline Couple, 4+ & 0.7765 & 0.0092 & 0.5723 & 0.0099 & 0.4892 & 0.0088 \\
\hline Arr06 & 1.4911 & 0.1863 & 0.4924 & 0.1923 & 0.8764 & 0.0986 \\
\hline Arr718 & 0.8568 & 0.1596 & 0.4178 & 0.1906 & 1.1214 & 0.0972 \\
\hline Arrage18plus & 1.1705 & 0.1588 & 0.8126 & 0.1902 & 1.4690 & 0.0969 \\
\hline Arr68 & -2.8964 & 0.6881 & -1.9600 & 0.4298 & -0.2778 & 0.2649 \\
\hline Arrmiss & -1.1537 & 0.0993 & -0.1463 & 0.0335 & 0.0099 & 0.0234 \\
\hline Woman & 0.1900 & 0.0021 & 0.1325 & 0.0021 & 0.1377 & 0.0022 \\
\hline MDC & -0.2424 & 0.1585 & 0.0634 & 0.1901 & -0.3871 & 0.0972 \\
\hline Turkey & 0.1790 & 0.1593 & 0.7457 & 0.1903 & 0.3468 & 0.0975 \\
\hline Ex-Yugo & -0.0247 & 0.1601 & 0.4377 & 0.1908 & -0.0041 & 0.0980 \\
\hline Iraq & 0.0476 & 0.1986 & 0.7924 & 0.1926 & 0.5322 & 0.0987 \\
\hline Poland & - & - & - & - & 0.3453 & 0.0977 \\
\hline Lebanon & 0.1603 & 0.1886 & 0.7969 & 0.1909 & 0.6376 & 0.0983 \\
\hline Somalia & 0.2453 & 0.2046 & 0.8373 & 0.2031 & 0.2566 & 0.0988 \\
\hline Pakistan & 0.4371 & 0.1598 & 1.0100 & 0.1908 & 0.5119 & 0.0983 \\
\hline Iran & -0.0573 & 0.1821 & 0.7360 & 0.1906 & 0.1589 & 0.0982 \\
\hline Other countries & 0.0869 & 0.1589 & 0.5472 & 0.1902 & -0.0014 & 0.0972 \\
\hline YSM_MDC & -0.0543 & 0.0077 & -0.0139 & 0.0047 & -0.0248 & 0.0030 \\
\hline YSM_MDC2 & 0.0007 & 0.0006 & -0.0008 & 0.0003 & -0.0000 & 0.0001 \\
\hline YSM_LDC & -0.1158 & 0.0057 & -0.0820 & 0.0036 & -0.0548 & 0.0022 \\
\hline YSM_LDC2 & 0.0049 & 0.0004 & 0.0033 & 0.0002 & 0.0017 & 0.0001 \\
\hline No. of observations & & 408561 & & 451296 & & 519244 \\
\hline Log likelihood & & -903881 & & -893062 & & -843475 \\
\hline
\end{tabular}

In contrast to Sweden, single parents have a significantly higher low income risk in all three years, and not in the most recent periods only. Also, being a woman is consistently found to increase the low income risk significantly in Denmark. Regarding the impact from arriving at different ages all coefficients are significant positive and for 1990 and especially for 1997 we find the expected relative size between the coefficients, i.e. still higher contributions cet. par. to the low income risk the higher is the age at arrival. 
By national origin we find an interesting pattern relative to the excluded group of natives. Back in 1984 we find only one significant and positive coefficient to coming from Pakistan. For other countries of origin the coefficients are insignificant reflecting that guest worker immigrants were still dominating in size at that time relative to tied movers and refugees. In 1990 and 1997 the picture is very much different with dominance of significant positive coefficients. The only exception is for immigrants coming from the group of more developed countries for whom we find a significant negative coefficient in 1997 while no significant difference is found relative to natives in 1984 and 19990. Finally, looking at the coefficients to years since migration we find the same effect as in Sweden, i.e. significantly decreasing low income risks with duration of residence in Denmark.

Education is well known to be among the important determinants regarding entry to a job in another labour market. In this way education is expected to be an important determinant for the low income risk. Educational data are however only available for 1997 and here in a less than perfect form, i.e. as a mix of registered education in the host country and self reported education in the home country. With this reservation in mind we show in Table 4 the results from entering two dummy variables for having a long education and having an intermediate education with short or no post school education as the excluded category. The educational variables are significant with the coefficient to having a long education being the highest in absolute terms. The other coefficients do not differ much regarding signs and significance from what we found in Tables 2 and 3. Education as mentioned is important regarding entry to the labour market which is expected to be the most efficient mechanism to reduce the low income risk. Unfortunately, individual labour market data are only available in the Danish data set. Separate estimations with the Danish data including individual labour market variables show the expected strong effects from succesful labour market integration on the poverty risk. 
Table 4. Determinants of low income incidence in 1997. First generation immigrants and natives. Denmark and Sweden. Including educational variables.

\begin{tabular}{|c|c|c|c|c|}
\hline & \multicolumn{2}{|c|}{ Denmark } & \multicolumn{2}{|c|}{ Sweden } \\
\hline & Coefficient & Std. Dev. & Coefficient & Std. Dev. \\
\hline Constant & -0.2013 & 0.0023 & -0.4049 & 0.0048 \\
\hline Age 39 & -0.8165 & 0.0031 & -0.8431 & 0.0063 \\
\hline Age 49 & -1.0970 & 0.0036 & -0.9834 & 0.0072 \\
\hline Age 59 & -1.2396 & 0.0042 & -1.0549 & 0.0081 \\
\hline Age 60 & -0.9807 & 0.0049 & -1.1620 & 0.0124 \\
\hline Single, child & 0.3246 & 0.0044 & 0.2649 & 0.0082 \\
\hline Couple, 0 ch. & -0.9164 & 0.0032 & -0.6977 & 0.0088 \\
\hline Couple, $1-2$ ch. & -1.0120 & 0.0036 & -0.5475 & 0.0072 \\
\hline Couple, 3 ch. & -0.3105 & 0.0059 & -0.1757 & 0.0117 \\
\hline Couple, 4+ & 0.5415 & 0.0090 & 0.5099 & 0.0164 \\
\hline Arr06 & 0.8118 & 0.0999 & 0.3957 & 0.0182 \\
\hline Arr718 & 0.9590 & 0.0985 & 0.2966 & 0.0105 \\
\hline Arrage18plus & 1.3585 & 0.0982 & 0.4719 & 0.0066 \\
\hline Arr68 & -0.4392 & 0.2694 & -0.0395 & 0.0584 \\
\hline Arrmiss & 0.0213 & 0.0236 & - & - \\
\hline Woman & 0.1334 & 0.0023 & 0.0646 & 0.0046 \\
\hline MDC & -0.3284 & 0.0986 & 0.3422 & 0.0163 \\
\hline Turkey & 0.2087 & 0.0988 & 0.9254 & 0.0341 \\
\hline Ex-Yugo & 0.0040 & 0.0993 & 0.1283 & 0.0227 \\
\hline Iraq & 0.5881 & 0.1000 & 0.4720 & 0.0302 \\
\hline Poland & 0.4190 & 0.0990 & 0.0409 & 0.0300 \\
\hline Lebanon & 0.5541 & 0.0996 & 0.7403 & 0.0355 \\
\hline Chile & - & - & 0.1982 & 0.0356 \\
\hline Somalia & 0.2174 & 0.1001 & - & - \\
\hline Pakistan & 0.4752 & 0.0996 & - & - \\
\hline Iran & 0.1810 & 0.0996 & 0.5061 & 0.0274 \\
\hline Other countries & -0.0033 & 0.0986 & 0.4206 & 0.0203 \\
\hline YSM_MDC & -0.0193 & 0.0031 & -0.0384 & 0.0013 \\
\hline YSM_MDC2 & -0.0001 & 0.0001 & 0.0004 & 0.0000 \\
\hline YSM_LDC & -0.0508 & 0.0022 & -0.0257 & 0.0019 \\
\hline YSM_LDC2 & 0.0016 & 0.0001 & 0.0002 & 0.0000 \\
\hline Educ_medium long & -0.3613 & 0.0024 & -0.0294 & 0.0048 \\
\hline Educ_long & -0.6075 & 0.0043 & -0.3533 & 0.0086 \\
\hline Educ_noinfo & 0.3758 & 0.0054 & 0.6719 & 0.0132 \\
\hline No. of observations & & 519244 & & 129705 \\
\hline Log likelihood & & $\begin{array}{l}-819631 \\
\end{array}$ & & -211691 \\
\hline
\end{tabular}




\section{Low Income Risks - Examples}

The results in regressions like those reported in Tables $2-4$ makes it possible to identify patterns of significance for the great battery of explanatory variables across the two countries and over time. But they do not convey any obvious information regarding the variability in low income risk between individuals with specific characteristics. To give an idea of the magnitude of these risks we show in Box 1 the low income risk based on the 1997 estimations for a number of individuals with specified background variables.

All individuals in Box 1 are males and the calculated risks are based on 1997 estimates excluding education variables. The top panel shows the risk for a man coming from Turkey, being 35 years old, living in a couple with 3 children. We calculate the estimated poverty risks for six different durations of residence in Denmark or Sweden. Looking at an ethnic group, the Turks, living in about the same number in Denmark and Sweden and characterized by the same arrival pattern, we find approximately the same level of the low income risk in the two countries as well as the same profile in the variation with the duration of residence.

This is not the case when we proceed to the example shown in the next panel in Box 1, being an Iranian with the same background characteristics as the Turk in the top panel. In both countries the poverty risk is lower than what is found for the Turkish man at all durations of residence. The ranking cross country is however much different with the highest poverty risk in Denmark at all durations. The different cross-country pattern in this case could reflect a better labour market integration in Sweden for Iranians which again could be due to on average better education among those Iranians who emigrated to Sweden. In the third panel we change to a person coming from the group of more developed countries, everything else kept constant. Once again, the profiles for the low income risk goes down. For this group, however, the level is roughly the same in Denmark and Sweden. In the three lower panels in Box 1 we look at a 25 year old man with the same national origin as in the upper three panels, but being single and without having children. The risk levels are much higher, but the profiles across ethnic groups and across countries correspond well with the findings in the three upper panels. Overall, the examples in Box 1 seem to indicate that part of the higher Danish low income risk among immigrants in the aggregate is due to compositional differences including differences in arrival time patterns as we find approximately the same low income probabilities for the two groups, Turks and immigrants from more developed countries, where arrival patterns, return migration patterns and labour market integration differs only little between Sweden and Denmark. In Box 1 we include for comparison the poverty risks for two types 
of natives, i.e. a 35 years old male living in a couple having 3 children and a 25 years old living as single and being without children. The poverty risks are nearly the same in Denmark and Sweden and at the same level as for comparable immigrants from the MDC group of countries.

Box 1. Background characteristics and low income risk in 1997- a survey of cases.

\begin{tabular}{|c|c|c|c|c|c|c|}
\hline Age & Family status & Children & $\begin{array}{l}\text { National } \\
\text { background }\end{array}$ & YSM & Risk SW & Risk DK \\
\hline 35 & Couple & 3 & Turkey & 5 & 0,49 & 0,49 \\
\hline 35 & Couple & 3 & Turkey & 10 & 0,43 & 0,44 \\
\hline 35 & Couple & 3 & Turkey & 15 & 0,37 & 0,41 \\
\hline 35 & Couple & 3 & Turkey & 20 & 0,27 & 0,29 \\
\hline 35 & Couple & 3 & Turkey & 25 & 0,24 & 0,33 \\
\hline 35 & Couple & 3 & Turkey & 30 & 0,24 & 0,22 \\
\hline 35 & Couple & 3 & Iran & 5 & 0,29 & 0,42 \\
\hline 35 & Couple & 3 & Iran & 10 & 0,23 & 0,36 \\
\hline 35 & Couple & 3 & Iran & 15 & 0,19 & 0,34 \\
\hline 35 & Couple & 3 & Iran & 20 & 0,12 & 0,23 \\
\hline 35 & Couple & 3 & Iran & 25 & 0,10 & 0,27 \\
\hline 35 & Couple & 3 & Iran & 30 & 0,11 & 0,17 \\
\hline 35 & Couple & 3 & MDC & 5 & 0,24 & 0,26 \\
\hline 35 & Couple & 3 & MDC & 10 & 0,18 & 0,22 \\
\hline 35 & Couple & 3 & MDC & 15 & 0,13 & 0,19 \\
\hline 35 & Couple & 3 & MDC & 20 & 0,08 & 0,09 \\
\hline 35 & Couple & 3 & MDC & 25 & 0,06 & 0,07 \\
\hline 35 & Couple & 3 & MDC & 30 & 0,06 & 0,02 \\
\hline 35 & Couple & 3 & Native & - & 0,07 & 0,06 \\
\hline 25 & Single & 0 & Turkey & 5 & 0,85 & 0,89 \\
\hline 25 & Single & 0 & Turkey & 15 & 0,72 & 0,74 \\
\hline 25 & Single & 0 & Turkey & 20 & 0,71 & 0,67 \\
\hline 25 & Single & 0 & Iran & 5 & 0,69 & 0,85 \\
\hline 25 & Single & 0 & Iran & 15 & 0,51 & 0,68 \\
\hline 25 & Single & 0 & Iran & 20 & 0,50 & 0,59 \\
\hline 25 & Single & 0 & MDC & 5 & 0,64 & 0,72 \\
\hline 25 & Single & 0 & MDC & 15 & 0,42 & 0,49 \\
\hline 25 & Single & 0 & MDC & 20 & 0,39 & 0,41 \\
\hline 25 & Single & 0 & Native & - & 0,34 & 0,35 \\
\hline
\end{tabular}


In Figure 6 we take an individual with the same characteristics as in the top panel of Box 1 but assume the person has a higher education. In contrast to the profiles in Box 1 we find now that the ranking is slightly different between the countries at durations of residence up to 20 years with the lowest poverty risk found in Denmark and with the same estimated risk at longer durations. At very high durations of residence the results are fragile as the groups are small. In Figure 7 we show the results from corresponding calculations for those without any registered education. The poverty risk is $2-3$ times higher for individuals in this group compared with the highly educated.

Figure 6. Low income risk as function of years since arrival. A couple with 3 children, the head being 35 years, having a long education and coming from Turkey. Based on 1997 estimations, Table 4.

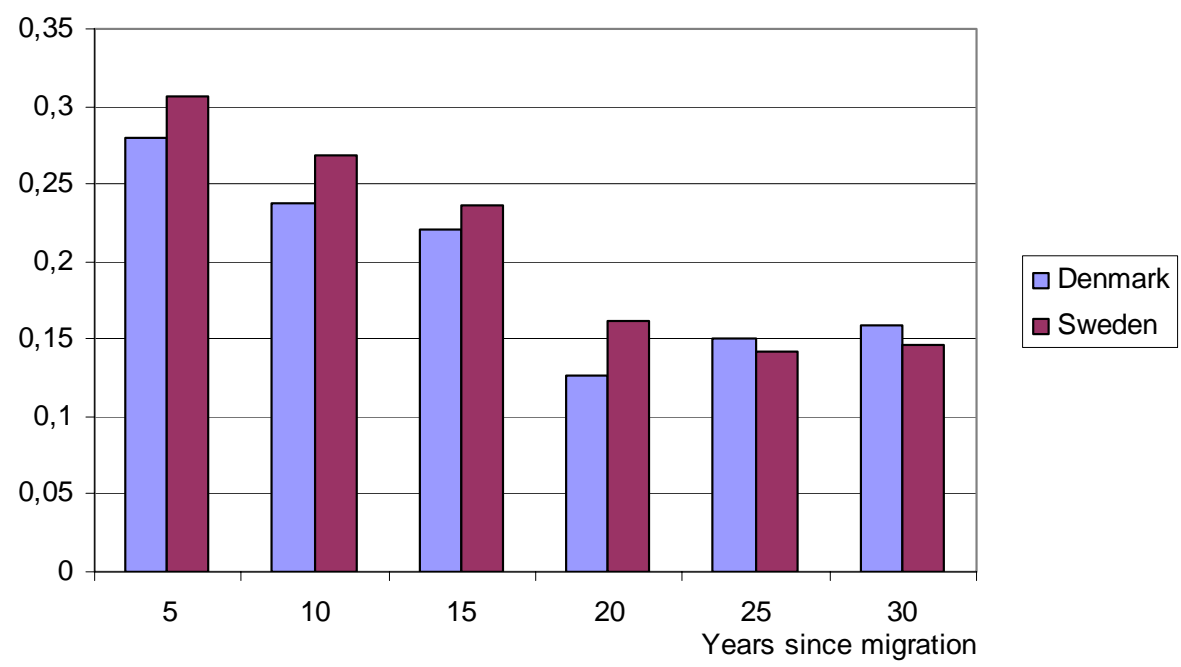


Figure 7. Low income risk as function of years since arrival. A couple with 3 children, the head being 35 years, without any registered education, and coming from Turkey. Based on 1997 estimations, Table 4.

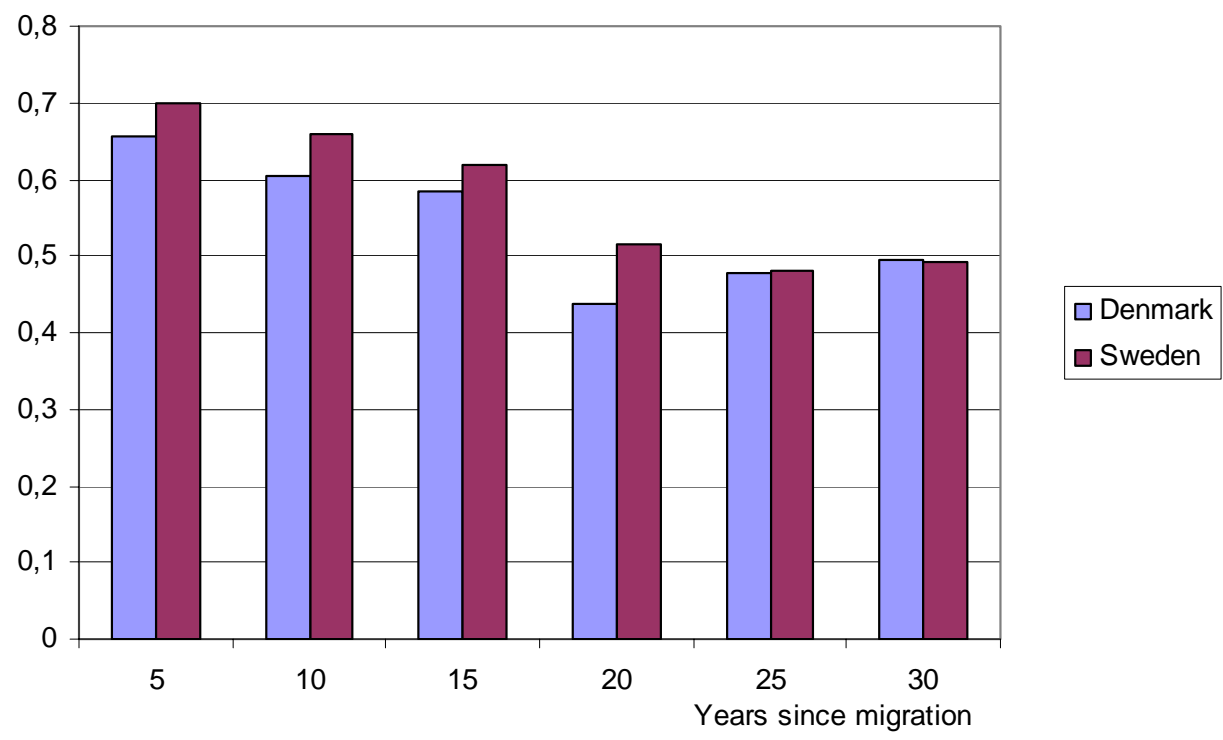

The relationship between the number of children in the family and the poverty risk seems to be an important factor in understanding the level and the trend in poverty rates in Sweden and Denmark. As the same rules regarding taxation and family benefits apply to immigrants and natives an obvious way to focus on the importance of the number of children is to calculate poverty rates for native families, thereby escaping the composition problem when looking at immigrants only. This is done in Table 5 showing the calculated poverty risk for natives relative to family structure based on the estimations for 1984, 1990 and 1997 for a 35 years old married man in different family situations. 
Table 5. Poverty risk for natives, Sweden and Denmark, according to family structure. Percent.

\begin{tabular}{|l|r|r|r|r|r|r|}
\hline & \multicolumn{3}{|c|}{ Sweden } & \multicolumn{3}{c|}{ Denmark } \\
\hline & 1984 & 1990 & 1997 & 1984 & 1990 & 1997 \\
\hline Single, children & 8,9 & 11,9 & 15,4 & 18,5 & 19,1 & 18,1 \\
\hline Couple, 1-2 children & 3,8 & 2,7 & 3,1 & 2,0 & 1,5 & 1,1 \\
\hline Couple, 3 children & 8,1 & 7,7 & 6,9 & 8,3 & 7,0 & 5,5 \\
\hline Couple, 4+ children & 17,4 & 17,2 & 21,8 & 31,1 & 27,0 & 23,2 \\
\hline
\end{tabular}

Looking first at a person living single with one or more children we find a strong increase in the poverty risk in Sweden from 9 to 15 per cent while the level in Denmark is stationary throughout at 18-19 per cent. For the "core" family type, a couple with 1-2 children, the picture is very different. In Sweden the level is stationary about 3 per cent while it is lower in Denmark in each year and declining from 2 to 1 per cent. For families with 3 children the level in Sweden decreases slightly from 8 to 7 per cent while it declines quite strongly in Denmark from a slightly higher level than in Sweden to a slightly lower level in 1997. Finally, we find a different story for big families with 4 or more children. The level in Sweden is high throughout, stationary in the 1980s and increasing in the 1990s. In Denmark the level is higher throughout but in contrast to Sweden, it is falling.

It should be emphasized that a much higher share of families from less developed countries than among natives belong in the category with 4 or more children. Consequently, the pattern in Table 5 is expected to be a major part of the explanation of the different poverty profiles shown in Figure 4, the cross-country as well as the pattern over time.

Finally, we examine whether the pattern in Table 5 based on our estimations seems to be related to the trend and structure in child and family benefits in the two countries. We have calculated the cumulated child cash benefits per child from birth to the 18 years birthday depending on the number of children between 1 and 5. The result is shown in Figure 8 showing that the structure in child benefits in Sweden is in favour of bigger families while in Denmark the cumulated benefits per child is independent of the number of children. The structural difference is in accordance with the risk calculations in Table 5. 
Figure 8. Cumulated child benefits in Euros per child relative to the number of children. (Calculations from CESifo-DICE database for institutional comparisons in Europe, 2002, www.cesifo.de/home).

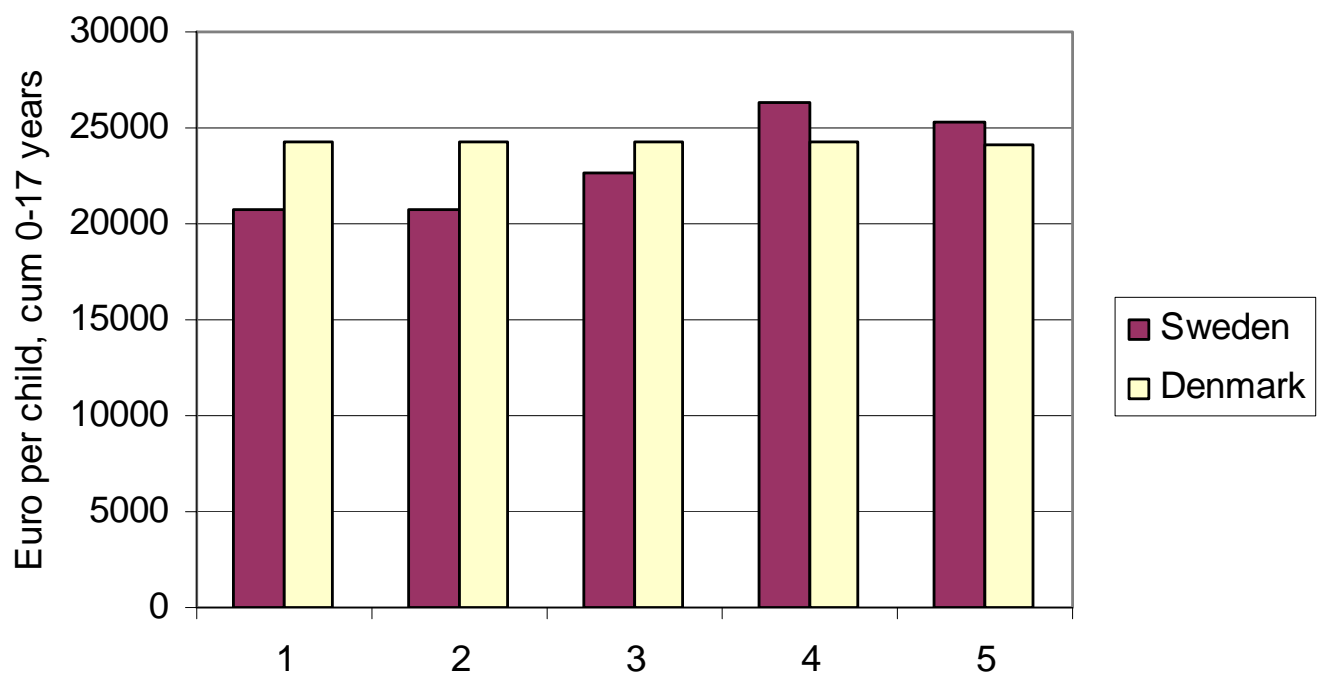

No. of children

Next, we look in Figure 9 at a summary measure of the relative importance of family cash benefits over time. As a percentage of GDP they develop quite differently, increasing in Sweden during the 1980s and decreasing to slightly below the 1980 level in the 1990s. At the same time relative family cash benefits are increasing in Denmark to the same relative level as in Sweden by the end of the period. 
Figure 9. Family cash benefits as a percentage of GDP, Sweden and Denmark, 1980-1998.

(Source: OECD Social Expenditure Database 1980-1998 (2001)).

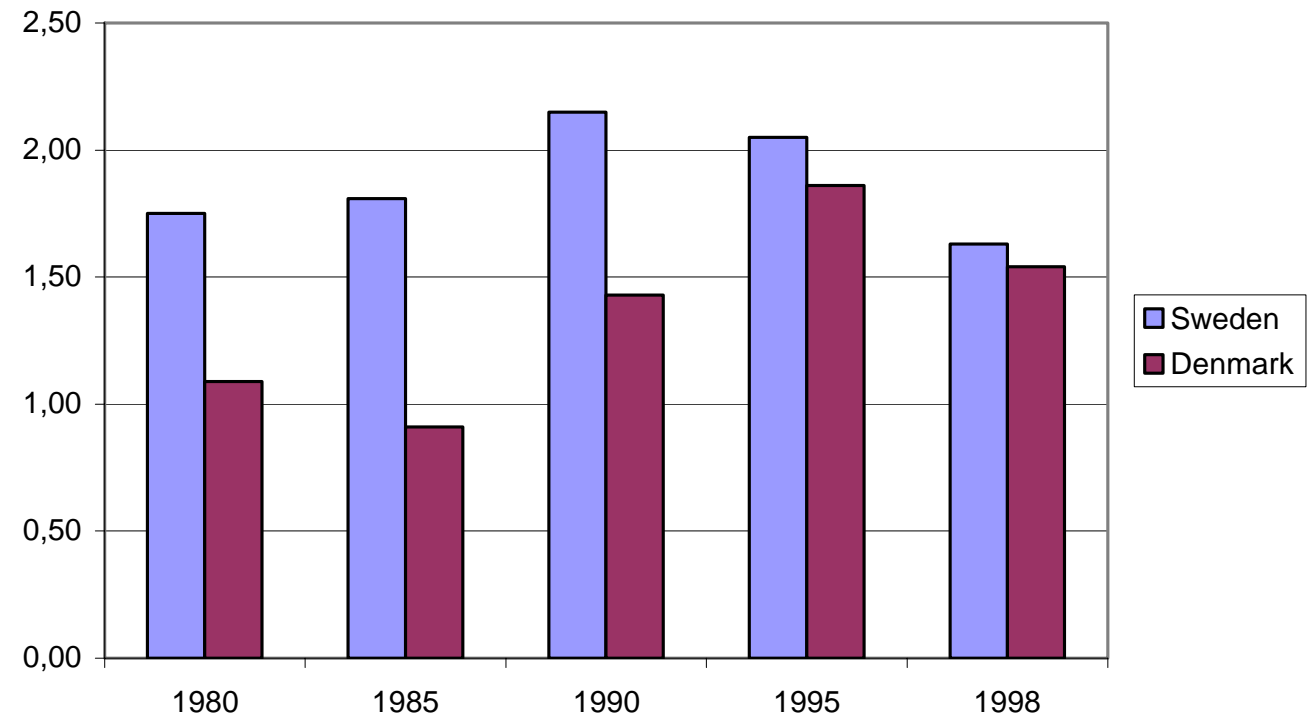

Based on the evidence in Table 5 and Figure 8 we expect that part of the differences in poverty rates between immigrants in Sweden and Denmark are related to structural differences in benefits to families with children in combination with higher fertility among immigrants from less developed countries. We illustrate the hypothesis in Figures 10 and 11 based on the poverty risk calculated from 1997 estimations for a male immigrant from Turkey, 35 years old, living in a couple and assumed to have 1 - 2 children in Figure 10 and 4 or more children in Figure 11.

We find the expected pattern where the Danish system is more favourable to families with few children while poverty rates are higher in Denmark at all durations of residence for families with 4 or more children. As few native families have 4 or more children in contrast to many families from less developed countries, differences in the structure of family cash benefits seem to explain part of the higher poverty rates among immigrants from less developed countries in Denmark. 
Figure 10. Poverty risk for male immigrant from Turkey, living in couple with 1-2 children, by different durations of residence in Sweden and Denmark. Calculations from 1997 estimates.

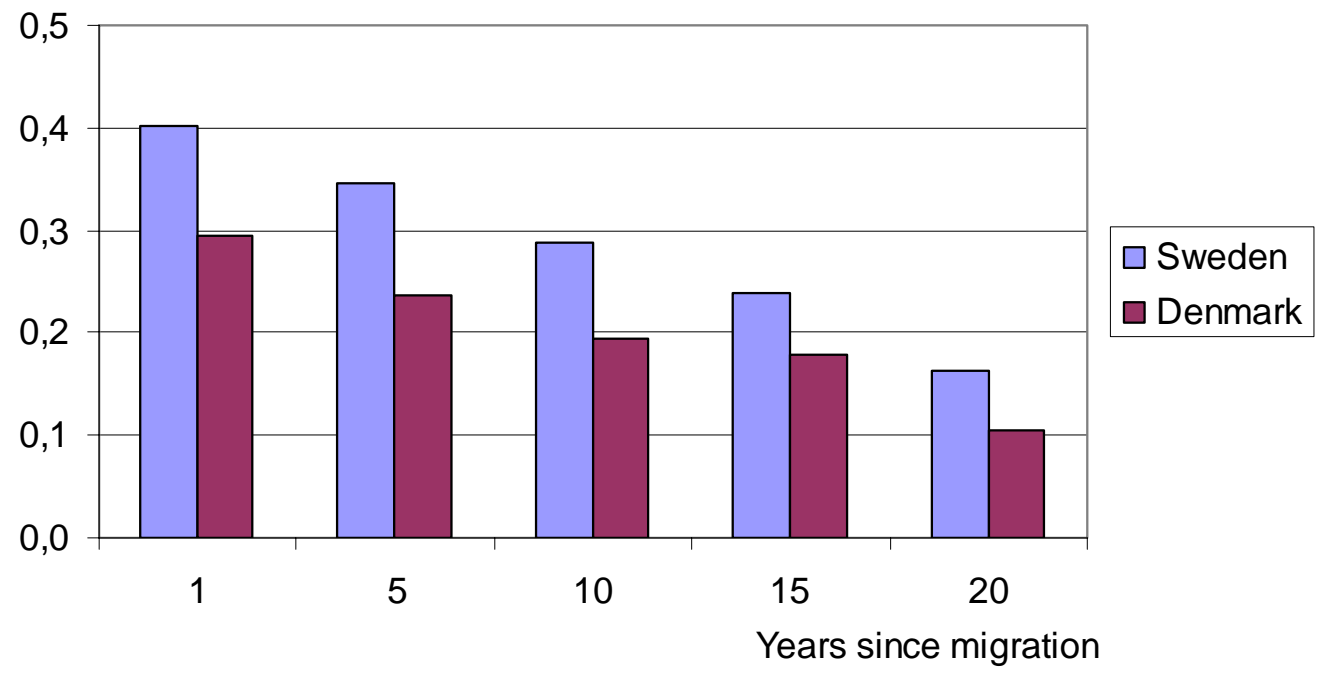

Figure 11. Poverty risk for male immigrant from Turkey, living in couple with 4 or more children, by different durations of residence in Sweden and Denmark. Calculations from 1997 estimates.

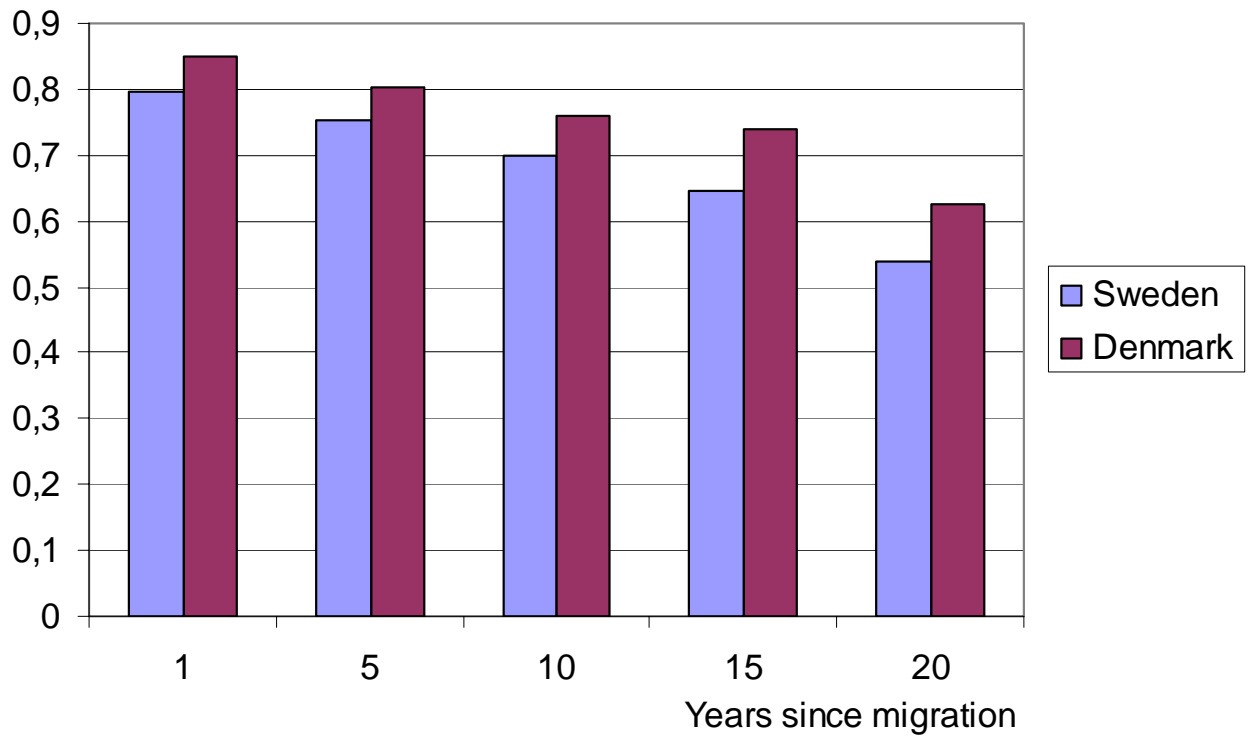




\section{Concluding comments}

We find some quite big differences in the level and trend of poverty rates in Sweden and Denmark. During the 1980s poverty rates among the native born were at the same low level in the two countries. In the 1990s the level among native born remained low in Denmark while it was increasing in Sweden following the macroeconomic shock to the Swedish economy in the early 1990s.

The significantly higher poverty rates among immigrants to Denmark than among immigrants to Sweden exist in spite of broad similarities in the structure and operation of the Swedish and Danish welfare states. We use two comparable panel data sets including immigrants as well as native born to estimate the impact on the individual poverty risk from a big number of background factors. We find significantly higher poverty rates for those younger than 30, for women and for people living in families with many children as well as for single adults living with one or more children. Educational variables are not available for the whole period covered by the analysis. Estimations on the most recent year in the data set shows the expected strong impact on poverty rates from having an education which for immigrants increases significantly the chances for succesful labour market integration. For the immigrants we find big differences in the impact on the poverty risk from the national origin and we find poverty rates declining with the duration of residence in the two host countries.

The conclusion from our analyses seems to be that the different summary poverty profiles between immigrants from less developed countries in Sweden and Denmark reflect two important factors. First, compositional differences regarding the stock and flows of immigrants to Sweden and Denmark. The importance of the composition effect is supported by calculations based on two fairly comparable groups, i.e. immigrants from Turkey and from the group of more developed countries. In both cases the differences between poverty risks are small contrary to the aggregate profiles. The other important factor seems to be differences in the structure and trend of income transfers to families with children. In Sweden they tend to favour big families while the opposite is the case in Denmark. Further, the relative generosity goes up in Denmark while relative benefits in Sweden exhibits a procyclical pattern, i.e. with increases in the 1980s and cutbacks in the 1990s.

The overall conclusion from a policy point of view is that low income status in the period we study is increasingly an immigrant phenomenon in two very comprehensive Scandinavian welfare states. This is most pronounced in Denmark where part of the explanation is a structure in family cash benefits more favourable to the typical native family structure than to the bigger families of 
immigrants from less developed countries. Another part of the difference relative to Sweden is found in later arrival of immigrants where a larger share is coming from countries where a fast integration in the labour market is more difficult.

\section{Literature}

Atkinson, T., B. Cantillon, E. Marlier and B. Nolan. 2002. Social Indicators. The EU and Social Inclusion. Oxford University Press.

Blume, K., B. Gustafsson, P.J. Pedersen and M. Verner. 2005. A Tale of Two Countries: Poverty among Immigrants in Denmark and Sweden since 1984. In G. Borjas and J. Cripps (eds.) Poverty, International Migration and Asylum. Palgrave-Macmillan.

Borjas, G.J. 1990. Friends or Strangers. The Impact of Immigrants on the U.S. Economy. Basic Books.

Ekberg, J. 1994. Är invandrare fattiga? (Are immigrants poor?) Ekonomisk Debatt, 22 (2), 169 - 177. (In Swedish)

Gustafsson, B 1997 Invandrares försörjning (Income maintenance of immigrants) pages 78 - 85 in Statens invandrarverk (National Immigration Board) Mångfald och ursprung. Rapport från ett multietiskt Sverige. (Diversity and origin. Report from a multiethnic Sweden) Norrköping (In Swedish).

Gustafsson, B. 1999 Fattigdom och andra mått på inkomststandard (Poverty and other income measures) in Socialstyrelsen (The National Board of health and Social Welfare) Social och ekonomisk förankring bland invandrare från Chile, Iran, Polen och Turkiet (Social and economic integration among immigrants from Chile, Iran, Poland and Turkey) Series Invandrares levnadsförhållanden 2. (In Swedish)

Hammarstedt, M. 2001. Disposable income differences between immigrants and natives in Sweden. International Journal of Social Welfare: 117-126.

Jensen, P. and P.J. Pedersen. 2004. To Stay or not to Stay? Return Migration from Denmark. Mimeo. University of Aarhus.

Kazemipur, A. and S.S. Halli. 2001. Immigrants and 'New Poverty': The Case of Canada. International Migration Review, Vol. 35, No. 4 (Winter 2001): 1129-1156.

Klinthäll, M. 2003. Return Migration from Sweden 1968-1996. Lund Studies in Economic History 21. Almqvist \& Wiksell International. Stockholm.

Poulsen, M.E. og A. Lange. 1998. Indvandrere i Danmark. /Immigrants in Denmark). Danmarks Statistik. København

Rosholm, M., K. Scott and L. Husted. 2000. The Times They are A-changin' Organizational Change and Immigrant Employment Opportunities in Scandinavia. IZA Discussion Paper No. 258. Bonn.

Schultz-Nielsen, M.L., O. Ingerslev, C. Larsen, G. V. Mogensen, N-K. Nielsen, S. Pedersen and E. Wadensjö. 2001. The integration of non-western immigrants in a Scandinavian labour market: The Danish experience. Statistics Denmark. Copenhagen.

Wadensjö, E. and H. Orrje. 2002. Immigration and the public sector in Denmark. Aarhus University Press. www.cesifo.de/home. Database for institutional comparisons in Europe. 